selves a good supply of carbon by keeping under all competitors by their close ufts, e. g., Plantago major.

III. Origin of Types.-There are two ways, according to Herbert Spencer, in which a stem may be r'eveloped from stalkless creeping fronds: first, by the inrolling or folding of the fronds forming a tube with adnate edges and resulting in the endogenous stem and monocotyledonous embryo; second, by the thickening and hardening of a fixed series of midribs, resulting in an exogenous stem and dicotyledonous embryo. Monocotyledonous leaves tend to show little distinction between blade and petiole, to assume a lanceolate or linear shape and parallel venation, because the fibro-vascular hundles will tend to run continuously over every part, since the leaves are mere prolongations of the stemforming portion, and because this venation is most convenient for long, narrow leaves. Of dicotyledonous leaves the opposites are true. The central type of leaf among monocotyls is long, narrow and rather fleshy; among dicotyls, simple, ovate and nearly ribless, or with faint digitate venation. Pinnate venation replaced palmate whenever circumstances caused leaves to lengthen faster than they broadened, the main ribs then being given off, not from the same point, but a little in front of one another. Pinnate ribs seem especially adapted to forest trees, probably protecting them against storms. The shapes of leaves thus depend upon two factors: first, the ancestrally inherited peculiarities of type and venation; second, the actual conditions to which the species is habitually exposed.

IV. Special Types.-Sessile leaves are particularly apt to be lanceolate. Decurrent leaves show the traces of the primitive unity of stem and leaf. Radical leaves, with long foot-stalks, will commonly be orbicular cordate and are most frequently produced from perennials with richly-stored root-stocks. The shapes of the leaves of climbers and trees have reference only to exposure to sunlight. Unequal exposure causes them to become oblique, e. g., Begonia and Tilia. Growth in dry soil and proximity to the sea, whether the plant grow in sand or mud, both tend to produce succulence.

C. R. B.

\title{
EDITORIAL NOTES.
}

The Report of the Botanical Section of the Acad. Nat. Sci., Philad, for 1882 , makes a good showing for the Herbarium, no less than 3,346 species having been added, one-third of which were new to the collection, and 100 of the genera not before represented. This is the largest annual addition since the organization of the Section, and is chiefly due to the zeal and liberality of Messrs. Redfield, Canby, Parker, Martindale, Meehan and others. Dr. Gray supplied more than 1,000 species, and Prof. Sargent furnished choice herbarium specimens of some of our rarer trees and shrubs. All this has thrown much labor on the Conservator, Mr. John H. Redfield, who has been ably assisted by the Philadelphia botanists above mentioned. 
Prof. C. E. Bessey, in the May Naturalist, very sensibly calls the attention of the Department of Agriculture to the subject of the parasitic fungi. Much money has been wisely expended by the government in the investigation of noxious insects, while no such provision has been made for the study of parasitic fungi, from the ravages of which there is an annual loss to our crops of millions of dollars. The rust, the smuts, and their allies ought to be thoroughly studied, and the government could do no wiser thing than to supply the Department of Agriculture with the means for carrying on such investigations.

IT SEEMS AS IF we we will have to give up the old idea that the growing point of phanerogams is a group of cells, as opposed to cryptogams with apical cell, for Dingler announces the discovery of an apical cell in the stems of seedling gymnosperms. And so phanerogams and eryptogams are gradually blending together, and paleontology and the microscope have caused to vanish our once "hard and fast line."

The Journal of Botany for April contains a list of the new genera and species of phanerogams published in periodicals in Britain in 1882. The list is a formidable one, containing 16 new genera and 357 species, mostly from Asia, South America and Madagasear. This surely indicates wowderful activity, both in the field and in the herbarium.

THE STARCH GRAINS of seeds, especially of the bean and pea in which they are quite large, are almost always cracked by the loss of water in drying, the cracks radiating from the nucleus, because the interior layers contain proportionally more water. That the above statements are true may be easily demonstrated experimentally in the following way: Dry some fresh potato starch (which previous examination has shown to be sound) over a water-bath at a temperature of about $60^{\circ} \mathrm{C}$. On re-examining the grains they will be found cracked radially. By treatment with absolute alcohol the process of cracking may be watched. Scrape the surface of a fresh-cut potato and dry the scrapings on blotting paper. Transfer to a slide and cover with 100 p.c. alcohol. In a few minutes the fissuring will begin, the first one always transverse to the long axis of the grain, or at right angles to the line of greatest contraction.

The Royal Gardens, at Kew, England, through the wise management of their officers and the liberal financial support which they receive, have become the center for the botanical and horticultural interests of the British Empire. The Report for 1881 shows something of the large amount of very varied and useful work which was carried on in and through them during that year. The Report contains reports from the Colonies and accounts of the progress of experiments in the culture of important economical plants, such as India rubber, Cinchona and Coffee.

WhAT HAVE BEEN called, by a stretching of the term, non-calcareous cystoliths, have been detected by H. Molisch in the pith of Goldfussia isophylla, G. glomerata and Ruellia ochroleuca. They occupy the interior of polyhedral or cylindrical sclerenchymatous cells which are scattered among the parenchyma. "These "cystoliths" resemble the normal ones in the same plant in form, but 
differ from all previously described ones in being attached to the cell-wall by several pedicels and in the ahsence of calcium earbonate. Their reactions indicate that they are composed of slightly lignified cellulose.

F. LudwiG calls attention in Kosmos to the flower of one of the Aroider (Philodendron bipinnatifidum), whose structure is such as to fit it for fertilization by snails, which, attracted by a strong nutmeg odor, creep into the spathe and crawl about over the flowers. The snail is certainly the last animal to be suspected of any connection with the cross-fertilization of flowers. What next?

The meeting of the American Assnciation of Science at Minneapolis next August will give an admirable opportunity for botanists to become acquainted with an interesting flora. Probably the first plant to attract attention upon arriving in the city is the northern wormwood, Artemisia frigida, with delicate whitened foliage elothing the rocks and banks below the Falls of St. Anthony. The other flowering plants meriting attention are numerous. The region is also rich in Characee and other fresh-water algæ, especially Nostocacee and Desmidece. The long excursions will doubtless go into districts of still more unfamiliar vegetation. The meeting should command a larger attendance of botanical students and collectors than heretofore.

The THEories in regard to the structure and growth of the cell-wall are having a thorough overhauling at the hands of German histologists. A résumé of Prof. Strasburger's last work, in which he criticises the generally-received Nægelian hypothesis, has already been given (vide, p. 172, this volume). In addition, now comes F. Schmitz, who adduces further arguments from the structure of the cell-wall in the filamentous algæ, in support of his view that the growth of the cell-wall in surface as well as in thickness is due to apposition and not to intussusception. Von Höhnel, after examining the wall of bastfibers and other cells, comes to the conclusion that the wall is not composed of crystalline micellæ. All the phenomena exhibited by cell-walls with polarized light he believes can be explained by a simpler theory, and one which also explains some phenomena of swelling up of the wall not hitherto explicable on the micellar hypothesis. (See Bot. Zeit. xL, pp. 595 and 616, for an account of his theory of molecular tensions.) While the discussion is thus running it will be well for teachers and lecturers to hold lightly to the Nægelian theory of micellæ at least, and possibly also to that of intussusceptive growth.

IT SEEMs that the effect of free oxygen upon quiescent bacteria is so great that the presence of the trillionth of a milligram of the gas can be detected by their movements; and this fact is being applied in the study of the work of assimilation in relation to various colors, one result of which is to show that there must be a series of colors other than that of chlorophyll which possess thepower of assimilation.

IT IS NOT CONSIDERED good taste to apologize for one's own appearance, but the April Gazette must be our excuse. We are to be congratulated that it made its appearance in any shape, for it fell into most incompetent hands. Having now contracted with a firm conceded to do the best work in the State, it is 
expected that hereafter there will be nothing to offend the eye of the most fastidious.

Prof. J. E. Todn, of Beloit, Wis., observes that in Psoralea argophylla a joint is formed in the stem very near the top of the ground, as perfect as that separating a leaf from the stem. "It cuts through all the tissues so that when the top dries up and begins to sway in the wind, it is broken off very readily or evenly." Thus they are rolled across the prairie and their seeds are disseminated.

Mr. Thos. H. Corry has been studying the development and mode of fertilization of the flowers of Asclepias Cornuti and has made some important additions to the work done by R. Brown, Payer, Schacht, and others. He shows that the so-called "stigma-disk" is formed by the fusion of the two style-apices, and not by that of the two stigmas. The anther wings, he finds, originate as lateral processes of the connective. In the matter of pollen formation the genus presents a "perfectly unique, isolated, and peculiar case of formation." These and many other results were announced recently to the Linnean Society of London.

Mr. J. G. BAKER has presented to the Linnean Society of London the second part of his "Contributions to the Flora of Madagascar," in which are descriptions of 160 new Gamopetalc. A new genus is described allied to Cinchona. Several new genera of Acanthacere are deseribed, among which is Monachochlamys, so named because each one of the numerous flowers is contained in a persistent spathaceous bract, like the hood of a Franciscan monk.

The short paper by Dr. A. L. Childs in the Popular Science Monthly for December, 1882, (vide Bот. GAz., this volume, page 163 ), has called out a vigorous rejoinder from Mr. J. B. Strawn, C. E. Mr. Strawn, referring to the wellknown fact that surveyors were in the habit of "blazing" trees on lines and at corners, says that, having had occasion many times to chop into such trees to satisfy himself of their identity, he has in every instance found the number of rings to correspond with the number of years which had elapsed since the blazing was done. The rings found by Dr. Childs he suspects to be those formed by trees when, from drought or some similar cause, the wood ceases to grow, but afterward, on account of copious rains and a high temperature, is forced into a second growth. Mr. Strawn also affirms that examination of trees of his own planting confirms him in the belief that the truthfulness of the "ring-record" may be depended upon.

\section{CURRENT LITERATURE.}

The Mycologic Flora of the Miami Valley, Ohio. By A. P. Morgan. From Jour. Cin. Soc. Nat. Hist. vol. vi., April, 1883.

Mr. Morgan has long been studying Fungi, and the above is a part of the result of his study in the Miami Valley. It is a most commendable effort to put the descriptions of these low forms of plant life within the reach of the many, 


\section{$2 \mathrm{BHL}$ Biodiversity Heritage Library}

1883. "Editorial Notes." Botanical gazette 8(5), 228-231.

https://doi.org/10.1086/325701.

View This Item Online: https://www.biodiversitylibrary.org/item/27484

DOI: https://doi.org/10.1086/325701

Permalink: https://www.biodiversitylibrary.org/partpdf/221442

\section{Holding Institution}

New York Botanical Garden, LuEsther T. Mertz Library

\section{Sponsored by}

MSN

\section{Copyright \& Reuse}

Copyright Status: NOT_IN_COPYRIGHT

This document was created from content at the Biodiversity Heritage Library, the world's largest open access digital library for biodiversity literature and archives. Visit BHL at https://www.biodiversitylibrary.org. 